\title{
An Examination of Product Structure and Efficiency within the Property Insurance Industry in China
}

\author{
Chenxi $\mathrm{Li}^{1}$, Gaiqin $\mathrm{Hu}^{2} \&$ J. Tim Query ${ }^{3}$ \\ ${ }^{1}$ China United Property Insurance Company Limited, China \\ ${ }^{2}$ Bank of Ningbo, Beijing Branch, China \\ ${ }^{3}$ College of Business, New Mexico State University, USA \\ Correspondence: J. Tim Query, College of Business, Department of Finance, New Mexico State University, Las \\ Cruces, NM 88003, USA. Tel: 1-575-646-5253. E-mail: tquery@nmsu.edu
}

Received: July 5, 2013

Accepted: August 29, 2013

Online Published: October 28, 2013

doi:10.5539/ibr.v6n11p80

URL: http://dx.doi.org/10.5539/ibr.v6n11p80

\begin{abstract}
The property insurance industry in China has achieved rapid growth since 1980s. However, further growth and development has been restricted for several reasons. While there are a variety of property insurance products, the product portfolio is unbalanced. Also, the early stages of these products are too simple to meet the diverse requirements of policyholders. Finally, certain products of different companies are somewhat duplicative. Based on the Structure Conduct Performance (SCP) analytical framework, the research paper analyzes various management index indicators and market competitive behaviors of China's property insurance market in recent years.

Utilizing germane data to perform an empirical study model, this paper elaborates on the importance of product structure on the property insurance market and proposes related measurements of practical and theoretical significance. These include the delicate management of the auto insurance business, expansion of the non-automobile property business, etc. The paper also provides suggestions on improving the current business structure, increasing the industry's probability of profitability, lowering management risk, strengthening the competitiveness of the business enterprise, and achieving a more productive and efficient increase in the development of China's promising property insurance market.
\end{abstract}

Keywords: property insurance company, business structure, adjustment measures

\section{Introduction and Literature Review}

\subsection{Introduction}

Since the 1980s, China's insurance industry has achieved sustainable and rapid growth. By the end of 2008, there were 8 insurance groups, 112 insurance companies, 10 asset management companies and 3.23 million employees in the insurance industry. The development of the insurance industry has also created a more competitive environment.

Property insurance is an important part of the insurance industry. According to government-provided industry statistics, national property insurance premium income reached 244.63 billion Yuan in 2008 (25.0 percent of the national insurance premium income), up from 17.2 percent in 2007. Automobile insurance premiums totaled 170.25 billion Yuan, up 14.7 percent, accounting for 65.6 percent of the national property insurance premium income. However, indemnity expenditures are also high and were more than 70 percent of the total premium income. The reasons are three-fold. First, many Chinese property insurance companies are focused primarily on scaling premium income and enlarging market share via a pricing strategy. Second, risk control from an underwriting perspective is somewhat optimistic and aggressive. Third, the virtual commoditization of product offerings is combined with a relatively undifferentiated approach to the marketing and service function by different insurance companies. Because of these factors, pricing has become the main competitive approach. This has resulted in a homogeneous business structure that has created a "bottleneck" type problem in China.

Upon examination of the successes of mature insurance markets in developed countries, it is reasonable to expect the competitive approach to be transformed from price competition to products competition in an open market. 
Chinese property insurance companies have recognized and attempted to address the problem, and even the government has intervened through a series of enacted policies. However, problems still exist, including a lack of innovation, business structure homogeneity and market failures related to supply and demand.

Through the incorporation of industrial organization theory, this paper analyzes the current status of the Chinese property insurance business structure and makes some comments and suggestions, which should improve the sustainable development of the domestic insurance market. Meanwhile, with the approaching twelfth anniversary of China's accession to WTO, this analysis of the structure practiced by property insurers can also give foreign property insurance companies an insight into the Chinese insurance market.

\subsection{Literature Review}

Most studies by scholars outside of China focus on enterprise competitiveness, operational efficiency, solvency, risk return, cash flow and comprehensive goals; trying to find the main variables affecting the property insurance business. Meanwhile, cultural acceptance and comfort with the theory of property insurance started relatively late in China. Research and monitoring of solvency, specific risk, asset liability management, and dynamic financial analysis started much later given the relative newness of the insurance industry, and there has been noticeable progress.

Throughout our literature review, we were unable to identify microcosmic and quantitative research within the context of property insurance structure, whether in domestic Chinese document or foreign articles originating in other countries. However, the theory of industrial organization has often been used to assess the state of development of certain industries; a review of these research methods is instructive in the analysis of the insurance business structure.

\subsubsection{Review of Foreign Studies}

Western theory of industrial organization sprouted in the 19th century, and "Principles of Economics" written by Marshall in 1890, was the leading authority on the topic. Marshall believed that the organization, particularly industrial organizations, can play an important role in improving the economic efficiency. However, the meaning of the term organization here is not explicit. In 1959, modern industrial organization theory system was formed through the book of industrial organization by Bain, and became the mainstream or orthodox theory of industrial organization factions.

The complete framework of industrial organization theory is that market structure restricts market conduct and then decides the market performance, referred to as the Structure Conduct Performance paradigm (SCP). The main factors which determine market structure are concentration, product differentiation and market entry (exit) barriers. Additional support from leading academics of the day allowed the theory of industrial organization to become a comprehensive theoretical system.

From the research of various countries and through the development of industrial organization, the theory has evolved into the content-rich and relatively independent Mesoeconomics. Mesoeconomics is a neologism that describes the study of economic provisions that are not based on either the macroeconomic reasoning of aggregate totals of demand, nor on the microeconomics of buying/selling and supply/demand, but rather on the importance that structures play in the formulation of these forces and their measurement. It is argued by Mesoeconomic thinking that structural influences are not adequately reflected in price signals and supply/demand curves, nor in Gross Domestic Product (GDP), large economic measures of inflation, unemployment rate, and other measures of aggregate demand and savings. After several years of revisions and development, initial results when applied to industry, manufacturing, etc. have been promising. The theories and ideas of market structure can also be applied to the analysis of the structure of property insurance. However, no specific discussion applicable to the Chinese property insurance industry has transpired and such a conversation is warranted.

Frequently, from an economics perspective, the discussion of insurance focuses on uncertainty issues. Specifically - within the realm of insurance - he concepts of insurance systems, methods, and principles are frequently discussed, mainly within the framework of risk theory, insurance companies and insurance practices of the business.

A review of the insurance economics textbooks published internationally finds that many scholars research areas such as insurance demand and supply, insurance products, insurance pricing and the relationship between insurance and the national economy. The development of insurance is considered from the angle of productivity and efficiency, but often industry organization theory is given little consideration. From the collected materials in non-China countries, there is still a paucity of research incorporating organization theory to a study of the 
development of the insurance industry.

\subsubsection{Domestic Research (China)}

Upon restoration of the domestic insurance industry, insurance theory was introduced to mainland China from Taiwan and other foreign countries. Mature insurance business practices and insurance operating principles were studied, and greatly assisted in the development of China's insurance industry. Nonetheless, traditional economic theory of insurance has many limits, such as emphasizing insurance market research and its security system, while ignoring the interrelated interests between insurance companies.

In regard to insurance theory, very few researchers apply the principles of industrial organization to the analysis of China's insurance industry. To our knowledge, only "China's Insurance Industry Organization Optimization", a book written by Professor Jiang Shengzhong, is authoritative and systemic regarding this issue. This book mainly focuses on the concept of optimization of the insurance industry organization, content, approach, policy and so on, but because there is no differentiation between property insurance and life insurance, some key issues are not adequately developed. Recently, even though some scholars' do not systematically propose insurance industry organization theory, they do acknowledge that an unreasonable business structure will affect the development of property insurance industry.

Jiang Shengzhong and Yi-Qiao (2000) characterize the current performance of the Chinese insurance industry market as poor. As with most industries, China's traditional theory emphasizes insurance industry growth. In practice, many insurance companies accentuate insurance premium income, market share, and institution-building, which could result in incremental increases in risk and irregularities in the insurance business activities. Sun Qi-xiang (2002) points out that auto insurance business lines account for more than half of the Chinese property insurance business, with other insurance lines, such as liability and credit insurance, developing quite slowly. Lu Ling (2002) contends that the rapid emergence of imitation products and substitute products make the life cycle of products shorter and shorter. When facing changing market conditions, enterprises cannot compete with inflexible products. Lei Tao (2006) finds that product supply should be closely linked to market demand states the importance of adjusting the pace of development and size of the products of both the non-auto and auto insurance business. Wang Xu-jin (2009) finds that while China's property insurance business has developed rapidly, it is still at a relatively low level of penetration and density. Hao Yan-su (2009) contends that the auto insurance lines of business dominate the success or failure of a majority of Chinese property insurance companies and the property insurance industry has on occasion suffered severe losses because of faulty underwriting and rate-making assumptions. Huang and Query (2007) note that property-casualty actuaries in China have to rely more heavily on subjective factors and instinct than do their counterparts in developed insurance markets, as much of the data used for ratemaking is unreliable.

Although many scholars have pointed out that the property insurance structure has many problems in China's insurance market, targeted specific empirical research and analysis is still needed. In this paper, we provide an in-depth study of the property insurance business structure, which should advance both theoretical and applied research in this area.

\section{The Status of China's Property Insurance Market}

\subsection{Expanding Premium Income and the Dominance of Automobile Insurance}

Since the resumption of the insurance business in 1980, Chinese property insurance premium income has increased from 460 million Yuan in 1980 to 287.6 billion Yuan in 2009. Excluding inflation, the average annual growth is about 29.9 percent, much faster than the 12 percent average growth rate of GDP. An obvious reason for this is that in 1980, the insurance industry was still in its infancy; in addition, China's rapid economic growth during these years expanded demand for insurance, and growth on the supply side was also faster (see Table 1).

Automobile insurance lines experienced exceptional growth, as those premiums increased from 7.28 million Yuan (1980) to 170.25 billion Yuan (2008), or an increase of 23,385 times (See Table 2). There are several reasons for this, including the acceleration of car ownership, an increase of the rate of insurance coverage, and the implementation of compulsory accident insurance. Due to the spirited efforts of the China Insurance Regulatory Commission (CIRC), by the end of 2008 the proportion of non-auto insurance business lines were 30.4 percent, up 1.5 percent, meanwhile, premium income of areas such as agricultural insurance, health insurance, guarantee insurance, and liability insurance also increased dramatically, with premium income increases of 112.5 percent, 155.1 percent, 50.7 percent, and 22.7 percent respectively (China Insurance Statistical Yearbook, 2009). 


\subsection{Management Entities and the Severity of Competition}

The domestic property insurance industry in China began in earnest in the 1980s, and quickly experienced significant changes. It went from only one property insurance company in 1985 to 51 companies by the end of 2009. The increase of these entities has changed the configuration of the property insurance, going from basically a monopolistic market dominated by PICC to an oligopolistic market structure. In 2009 five property insurance companies accounted for a combined 74.15 percent of the market, with a premium income exceeding 10 billion Yuan. The market share of the remaining 29 Chinese-funded property insurance firms is 24.79 percent, and the market share of 17 foreign and joint venture property insurers share is 1.06 percent.

Table 1. China's GDP and the property insurance premium income (1980-2009)

\begin{tabular}{|c|c|c|c|c|}
\hline Year & $\begin{array}{c}\text { GDP } \\
\text { billion Yuan }\end{array}$ & $\begin{array}{c}\text { Growth } \\
\%\end{array}$ & $\begin{array}{l}\text { premium income } \\
\text { million Yuan }\end{array}$ & $\begin{array}{c}\text { Growth } \\
\%\end{array}$ \\
\hline 1980 & 451.78 & 7.8 & 460 & - \\
\hline 1981 & 486.24 & 5.2 & 780 & 69.57 \\
\hline 1982 & 529.47 & 9.1 & 1028.4 & 31.85 \\
\hline 1983 & 593.45 & 12.08 & 1384 & 34.58 \\
\hline 1984 & 717.10 & 25.01 & 1991 & 43.86 \\
\hline 1985 & 896.44 & 13.5 & 3273 & 49.94 \\
\hline 1986 & 1020.22 & 13.81 & 5050 & 54.29 \\
\hline 1987 & 1196.25 & 17.25 & 7434 & 47.21 \\
\hline 1988 & 1492.83 & 24.79 & 10074 & 35.51 \\
\hline 1989 & 1690.92 & 13.27 & 12306 & 22.16 \\
\hline 1990 & 1854.79 & 3.80 & 14859 & 36.78 \\
\hline 1991 & 2161.78 & 9.20 & 18648 & 28.17 \\
\hline 1995 & 5847.81 & 10.5 & 57450 & 15.97 \\
\hline 2000 & 8944.22 & 8.00 & 59840 & 14.8 \\
\hline 2001 & 9731.48 & 7.50 & 68540 & 14.6 \\
\hline 2002 & 10239.79 & 8.00 & 77981 & 13.3 \\
\hline 2003 & 11652.85 & 9.00 & 86940 & 11.7 \\
\hline 2004 & 13651.5 & 9.50 & 108990 & 25.4 \\
\hline 2005 & 18232.1 & 9.90 & 122990 & 12.9 \\
\hline 2006 & 20940.7 & 10.7 & 150940 & 22.6 \\
\hline 2007 & 24661.9 & 11.4 & 1997.7 & 32.4 \\
\hline 2008 & 30067.0 & 21.9 & 2446.3 & 22.46 \\
\hline 2009 & 33535.3 & 11.54 & 2876 & 17.57 \\
\hline
\end{tabular}

Source: China Insurance Statistical Yearbook (1980-2009), China Statistical Yearbook (1980-2009) and China Insurance Regulatory Commission website.

Table 2. Vehicle insurance premiums in China (1980-2008) (Units: billion Yuan)

\begin{tabular}{lllllll}
\hline Year & $\mathbf{1 9 8 0}$ & $\mathbf{1 9 9 8}$ & $\mathbf{1 9 9 9}$ & $\mathbf{2 0 0 0}$ & $\mathbf{2 0 0 1}$ & $\mathbf{2 0 0 2}$ \\
premiums & 0.00728 & 28.098 & 30.642 & 37.3 & 42.2 & 47.2 \\
\hline Year & $\mathbf{2 0 0 3}$ & $\mathbf{2 0 0 4}$ & $\mathbf{2 0 0 5}$ & $\mathbf{2 0 0 6}$ & $\mathbf{2 0 0 7}$ & $\mathbf{2 0 0 8}$ \\
premiums & 54.0 & 74.5 & 85.8 & 110.8 & 148.43 & 170.25 \\
\hline
\end{tabular}

Source: China Insurance Statistical Yearbook (1980-2009). 
Although the number of insurance entities is increasing, premium income is growing and profitability is being improved, the overall level of property insurance market density and depth is still relatively low. Insurance depth is measured by total gross premiums written as a percentage of GDP. Insurance density is measured by total gross premiums written per capita. Government statistics for the period of interest to this study indicate that the depth of China's non-life insurance was only 1.0 percent as compared to 2.9 percent for the world; non-life insurance density was 33.7 U.S. dollars in China, and 264.2 U.S. dollars for the world (Swiss Re, Sigma 2000). The preponderant questions are: Why doesn't the profit growth match the property insurance market's rapid growth? What effect does homogenization of the product structure bring to the property insurance market? Within the context of these problems existing in the development of property insurance, we will utilize Industry Organization Theory, study the existing property insurance market, market structure and product structure, and recommend the optimal ways to efficiently and equitably develop the Chinese domestic insurance market.

\section{An Empirical Analysis of the Business Structure in Property Insurance}

There are numerous factors that are germane in the determination of the business structure, and here we focus our analysis on the three main factors: market concentration, regional differences in degree of development and product structure.

\subsection{Market Concentration}

\subsubsection{Analysis of Market Share}

Our analysis of market concentration is based on market share. As seen in Table 3, from 2004 to 2009, the top four Chinese property insurance companies who account for the largest market share of premium income, are PICC (Note 1), PING AN (Note 2), CPIC (Note 3) and CIC (Note 4) respectively. The vast majority of market share for the time frame of interest is held by these four companies.

The market share of other Chinese-funded insurance companies is much smaller, and each one is in a somewhat less competitive position. Because of few differences among these insurance companies, the competition will be more intense. Interestingly, the market share of foreign insurance companies is also small during this time period. This may be due to imperfections and inefficiencies in the Chinese insurance market and an uncertain legal environment, as well as a long period of acclimatization of some foreign-funded insurance institutions into the Chinese culture.

\subsubsection{Analysis of Market Concentration}

According to The OECD Glossary of Statistical Terms and industry organization theory, market concentration is a function of the number of firms and their respective shares of the total production (alternatively, total capacity or total reserves) in a market (Note 7). As an economic tool, market concentration is useful because it reflects the degree of competition in the market. Bain's (1956) original concern with market concentration was used to study industry monopoly and degree of competition. He divided it into six levels, as described in Table 4 below.

Table 3. Analysis of market share (2004-2009) (ten thousand yuan;\%)

\begin{tabular}{|c|c|c|c|c|c|c|c|c|c|c|c|c|}
\hline Company & 2004 & Proportion & 2005 & Proportion & 2006 & Proportion & 2007 & Proportion & 2008 & Proportion & 2009 & Proportion \\
\hline PICC & 6532582.1 & 58.09 & 6593644.6 & 51.47 & 7129936.8 & 45.12 & 8859179.8 & 42.00 & 10165607 & 41.56 & 11946412 & 39.92 \\
\hline CPPI & 1384917.1 & 12.32 & 1444037.4 & 11.27 & 1812268.7 & 11.47 & 2343304.4 & 11.00 & 2781677.5 & 11.37 & 3422794.8 & 11.44 \\
\hline PING AN & 1064057.4 & 9.46 & 1267451.5 & 9.89 & 1686247.1 & 10.67 & 2144953 & 10.00 & 2675134.4 & 10.94 & 3848338.2 & 12.86 \\
\hline CIC & 655317 & 5.83 & 1039821.5 & 8.12 & 1505655.9 & 9.53 & 1831098.5 & 9.00 & 1912480.7 & 7.82 & 1943962.9 & 6.50 \\
\hline TIAN $\mathbf{A N}^{5}$ & 512797.07 & 4.56 & 635071.5 & 4.96 & 638664.09 & 4.04 & 1002839.62 & 4.81 & 669774.97 & 2.74 & 700002.77 & 2.34 \\
\hline $\mathrm{CCP}^{6}$ & 153481 & 1.36 & 381532.52 & 2.98 & 632798.48 & 4.00 & 1002839.6 & 5.00 & 942448.75 & 3.85 & 1025302.8 & 3.43 \\
\hline $\begin{array}{l}\text { Chinese- } \\
\text { funded }\end{array}$ & 11109473 & 98.79 & 12643055.62 & 98.69 & 15612103.07 & 98.79 & 20622748.56 & 98.84 & 24174102.41 & 98.82 & 29611440.52 & 98.94 \\
\hline $\begin{array}{l}\text { Foreign- } \\
\text { controlled }\end{array}$ & 136017.24 & 1.21 & 98.69 & 1.31 & 191440.67 & 1.21 & 242095.64 & 1.16 & 288389.17 & 1.18 & 317548.53 & 1.06 \\
\hline Total & 11245491 & & 12811077.47 & & 15803543.75 & & 20864844.2 & & 24462491.59 & & 29928989.05 & \\
\hline
\end{tabular}

Source: China Insurance Regulatory Commission website (Note 5, Note 6). 
Table 4. Concentration style table

\begin{tabular}{lll}
\hline Type & $C_{4}(100 \%)$ & $C_{8}(100 \%)$ \\
\hline Oligopolistic market structure I & $75 \leq C_{4}$ & - \\
Oligopolistic market structure II & $65 \leq C_{4} \prec 75$ & Or $85 \leq C_{8}$ \\
Oligopolistic market structureIII & $50 \leq C_{4} \prec 65$ & $75 \leq C_{8} \prec 85$ \\
Oligopolistic market structureIV & $35 \leq C_{4} \prec 50$ & $45 \leq C_{8} \prec 75$ \\
Oligopolistic market structure V & $30 \leq C_{4} \prec 35$ & Or $40 \leq C_{8} \prec 45$ \\
Atomic style & - & - \\
\hline
\end{tabular}

Source: Bain, J. 1956. Barriers to New Competition, Cambridge, Mass: Harvard University Press.

On the basis of market share, we calculate $C R_{n}$, and use the indicators to measure market concentration in China's property insurance market.

Formula: $C R_{n}=\sum_{i=1}^{n} X_{i} / \sum_{i=1}^{N} X_{i}$

$X_{i}-$ Output value, production, sales or total assets of $i_{\text {th }}$ business entity, which is the property insurance premium income here.

$n-$ The number of the enterprises affected.

$N-$ The total number of industrial enterprises.

On the basis of the above model, we use the data from 1998 to 2009 to calculate Table 5 below.

Table 5. Concentration analysis table of Chinese properly insurance market in 1998-2009

\begin{tabular}{|c|c|c|c|c|c|c|c|c|c|c|}
\hline Year & 1998 & 1999 & 2000 & 2001 & 2004 & 2005 & 2006 & 2007 & 2008 & 2009 \\
\hline $\mathrm{CR}_{4}$ & 97.7 & 97.65 & 97.12 & 97.43 & 85.70 & 80.75 & 76.79 & 72.00 & 71.69 & 70.72 \\
\hline
\end{tabular}

Source: China Insurance Statistical Yearbook (1980-2009) and CIRC website.

From Table 5, we observe that the $\mathrm{CR}_{4}$ of the Chinese property insurance market has been steadily falling 97.7 percent (1998) to 70.72 percent (2009); and essentially moving from an Oligopolistic market structure I to Oligopolistic market structure II (Note 8). The initial concentration is high, and it may be caused by many factors, such as a policy history of closed-market operations. With the rapid and relatively controlled development of China's economy, small/medium sized insurance companies are growing and foreign/joint venture insurance companies are increasing in numbers, causing market concentration to decrease significantly. However, compared with world's major countries, China's property insurance market has a high market concentration, with the market concentration of the three top insurance companies in China being 2 or 3 times that of the top five insurance companies in many developed countries.

\subsection{Diversity of Regional Development}

On one hand, uneven development of an economy can lead to different regional market concentrations. In China, eastern coastal areas opened earlier, with good results for the development of the insurance industry. Therefore the competitive situation in those areas has gradually been diversified. Meanwhile, in the central and western regions, economic development is lagging and there are fewer new entities, so structural changes are very slow and market competition is at a comparatively low level. Overall, market concentration in the eastern provinces has declined more quickly than in the central and western provinces. As the barriers to entry are reduced and the degree of open competition increases, the market concentration will be expected to decrease further as market competition is more intensified.

On the other hand, the production structure exhibits characteristics that are regional in nature. From the analysis above, PICC has held the leading market share for many years, so we will use it as a proxy for the whole market. Specifically, 2008 data on PICC will be used as a case study. In Figure 1 on the next page we make the following observations: 
First, auto insurance, business property insurance and third party liability insurance are the main products in east, central and western regions. Motor vehicle insurance is the biggest line of property insurance, with market shares of 69.6 percent, 67.7 percent and 59.7 percent, respectively in the eastern, central and western regions. We can reasonably conclude that many aspects of motor vehicle insurance not only bring more premium income but add also more costs of compensation. Whether it is beneficial to development of property insurance companies has yet to be verified. Second, the premiums of cargo insurance in eastern regions and agricultural insurance in western regions are larger proportionally than similar products in other regions. The development of a regional economy is the direct reason for such differences. Third, while the premiums of engineering insurance and credit $\&$ guarantee insurance are still somewhat small, the market potential in these areas is enormous.

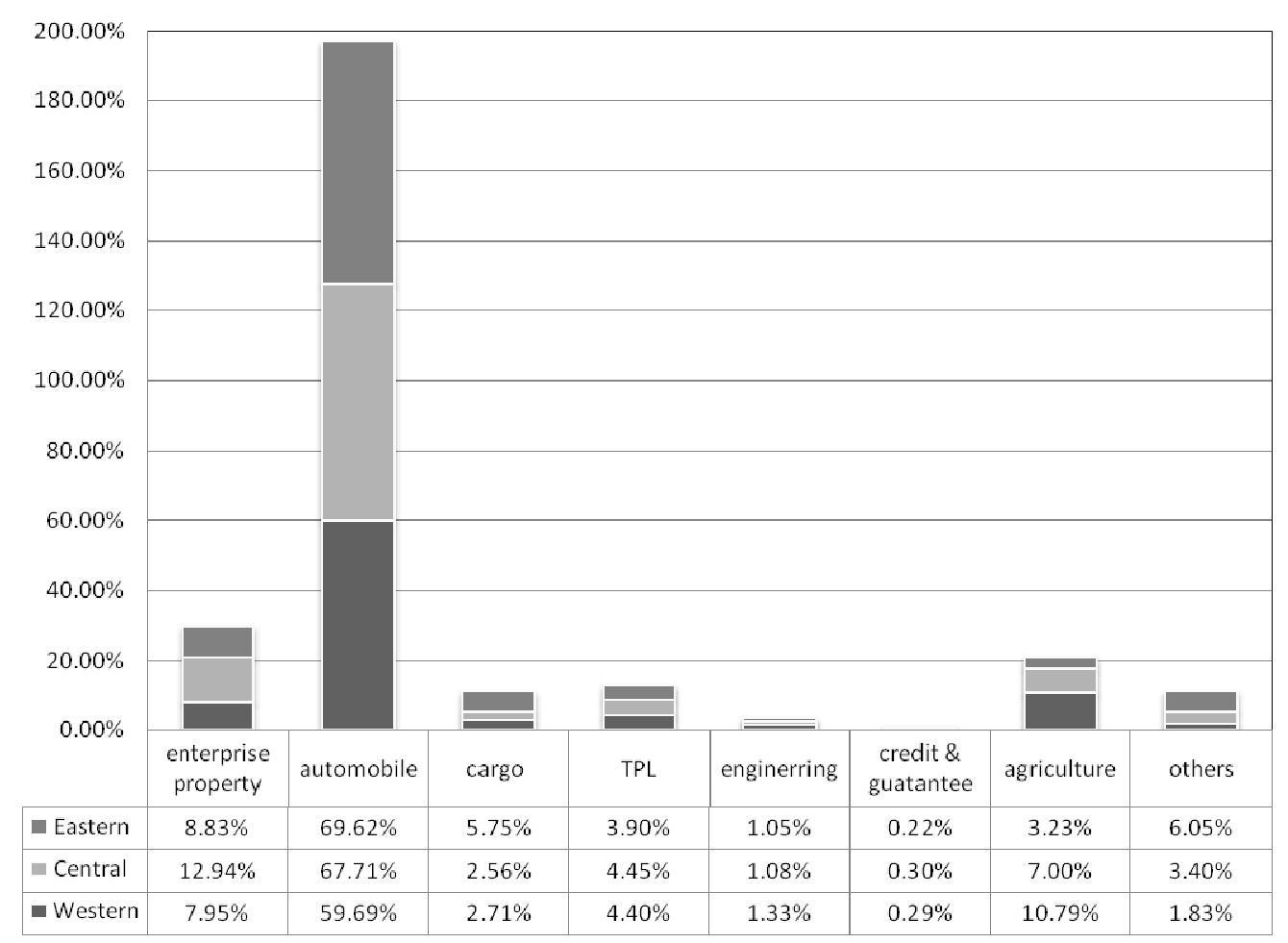

Figure 1. Product distribution in different regions of PICC (2008)

\subsection{Product Structures}

\subsubsection{The Balance of Products}

Whether viewing product structure nationally or regionally, the market share of auto insurance has a decided advantage. An empirical analysis is conducted to address the practicality of a seemingly over-reliance on a single line of insurance (Note 9).

\section{- Motor \& Non-Motor Insurance}

(1) The Impact on Premium Income

Assume Y1 as the Total Premium Income, NONAUTO as Non-auto insurance premium income, X1 as Vehicle insurance premiums. Eviews were used to regress the model.

$$
\begin{aligned}
Y 1= & 0.668100 \mathrm{NONAUTO}+1.204836 X 1+39.24548 \\
& (3.048945) \quad(25.88506)
\end{aligned}
$$

R-squared $=0.999497 \quad \mathrm{~F}=7946.255$

Via statistical tests of significance, we have t-statistics of vehicle insurance premiums and non-auto insurance premium income attained at 25.89 and 3.05. Obviously, both of these T-statistics are higher than $\mathrm{T}_{0.025}(11)=$ 2.228. Both of these variables are statistically significant at the $95 \%$ significant level. An R-squared equal to 0.999497 shows a high degree of goodness of fit. The F-statistic is $\mathrm{F}_{0.05}(2,8)=4.46$. Since this is well below the 
$5 \%$ critical value, the result is that vehicle insurance premiums and non-auto insurance premium income are jointly insignificant in this model.

From an economic viewpoint, the result that every parameter is non-zero means that Total Premium Income increases with increases in each lines of insurance. That is consistent with general economic interpretation. In addition, contributions of vehicle insurance premiums to total premium income are larger than that of non-auto insurance premium income. Specifically, total premium income increases 1.2 with a one unit increase in vehicle insurance premium, and only a 0.67 increase as one unit increases in non-auto insurance premium income. The contribution of auto insurance on total premium income is much larger than non-auto insurance.

However, the absolute proportion of premium income as a test product structure cannot be the only indicator of rationality. Within the context of an applied process, compensation is also a key factor.

(2) The Impact of Compensation

Assume Y2 is Total Indemnity, NONAUTO2 as Non-auto insurance indemnity, and C1 as Vehicle insurance indemnity. Eviews was used to regress the model.

$$
Y 2=0.896116 \text { NONAUTO2 }+1.133894 C 1+0.030326
$$

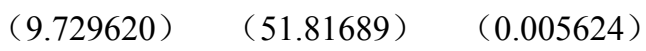

R-squared $=0.999800 \quad \mathrm{~F}=19982.95$

Via the test for statistical significance, the t-statistics of vehicle insurance indemnity and non-auto insurance indemnity are 51.82 and 9.73 respectively. Both of these t-statistics are higher than $\mathrm{T}_{0.025}(11)=2.228$. It illustrates that both of these two variables are statistically significant at the $95 \%$ significant level. An R-squared equal to 0.999800 shows a high degree of goodness of fittest. The F-statistic is $\mathrm{F}_{0.05}(2,8)=4.46$, and this is well below the $5 \%$ critical value, supporting the result that vehicle insurance and non-auto insurance indemnity are jointly insignificant in this model.

Again using an economic perspective, the coefficient of each variable is greater than 0 . We find that with the increase in insurance compensation, the sum also increased, and was economically significant. More specifically, there are 1.13 times as much compensation of automobile insurance for every increase by one unit and about 0.90 times as much that of non-automobile insurance for every increase by one unit. Our conclusion is that auto insurance has a greater impact on compensation.

Combining and analyzing formulas (1) and (2), we can see that, per each additional unit, automobile insurance not only resulted in a significant increase in total premium income, but also made a substantial increase in compensation. While a seemingly unchecked expansion of auto insurance does bring in added premiums, there are also business fees and a variety of other costs that may alter expected benefits.

\section{- Non-Motor \& Non-Motor}

(1) The Impact on Premium Income

We calculate the ratio of premium income of non-auto insurance to the total sum and use Excel to produce Figure 2.

1) Operating conditions of enterprise property insurance are basically the same as cargo insurance. From terms of absolute premium income, the necessity of these two products are increased by the recent growth of business enterprises, but the ratios of premium income of the two products to the total sum actually decreased year to year. There are two main reasons for this phenomenon. First, the growth rate of these two products is lower than that of the total premium, whose growth rate is 30 percent. Second, the development of new business property insurance has not kept pace with the general expansion of the private economy in China.

2) Homeowners insurance. The proportion of home property insurance is small. This insurance line peaked at 2.4 billion in 2002, and accounted for 3.08 percent of total Property insurance premiums. However, it declined significantly in 2003, and the premium income has been hovering around 1.3 billion Yuan since then.

3) Agriculture insurance. The share of agricultural insurance has always been low, which does not match China's standing as one of the world's largest agricultural countries. It declined from 1.41 percent (1998) to 0.51 percent (2006). A likely reason for this is that the risk exposures covered by agriculture insurance are more complex, and potential catastrophic risks are greater. However, the Chinese government has recently given more support to the agriculture insurance market, and it appears to have made a difference - with rapid growth of 2.55 percent (2007) and 4.53 percent (2008). 


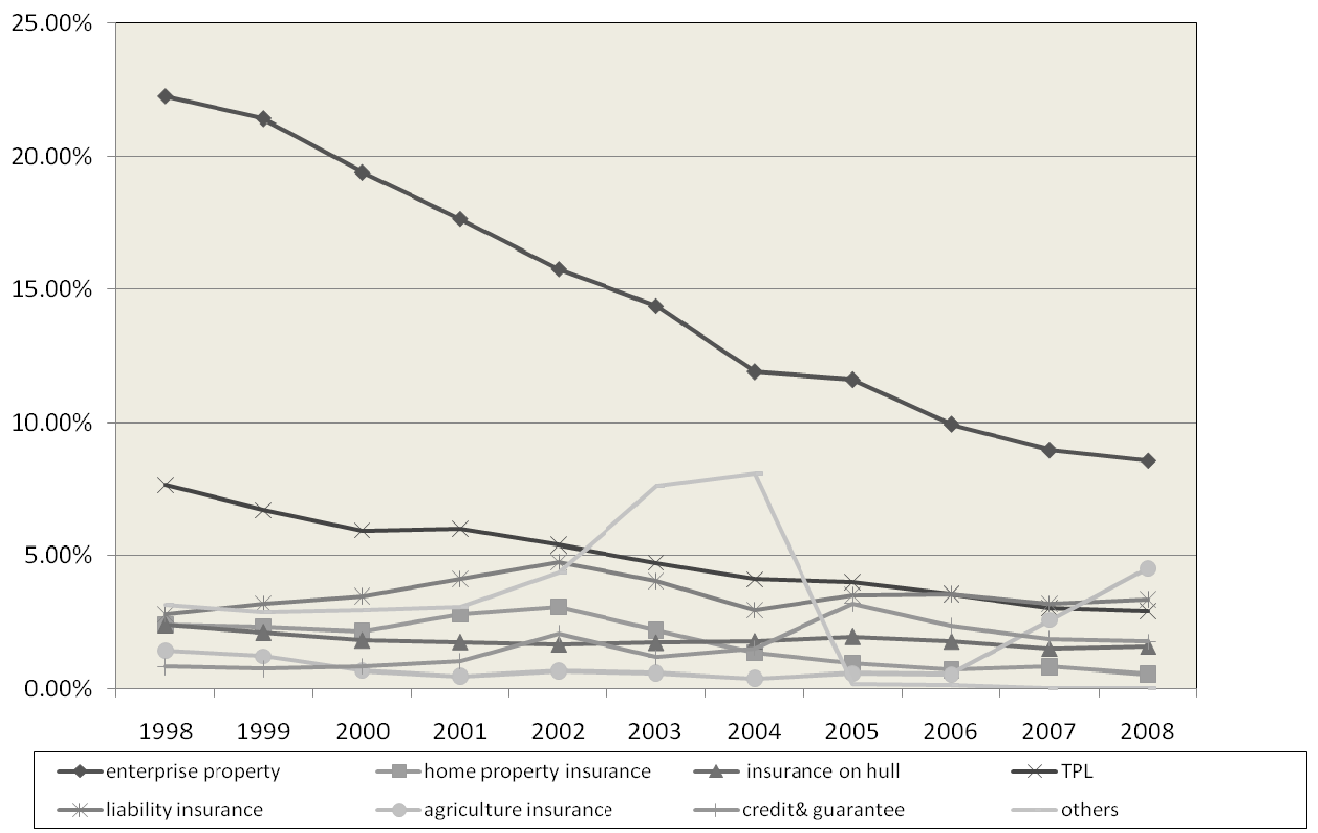

Figure 2. 1998-2008 Market share trend of non-auto insurance in China (1998-2008)

4) Liability insurance and credit $\&$ guarantee insurance. These lines account for an insignificant proportion of the total (Note 10), mainly due to inadequate laws and regulations in China and a lack of cultural awareness of insurance in these areas by the Chinese.

(2) The Impact on Compensation

We calculate the ratio of compensation of non-auto insurance to the total sum and use Excel to produce the results found in Figure 3.

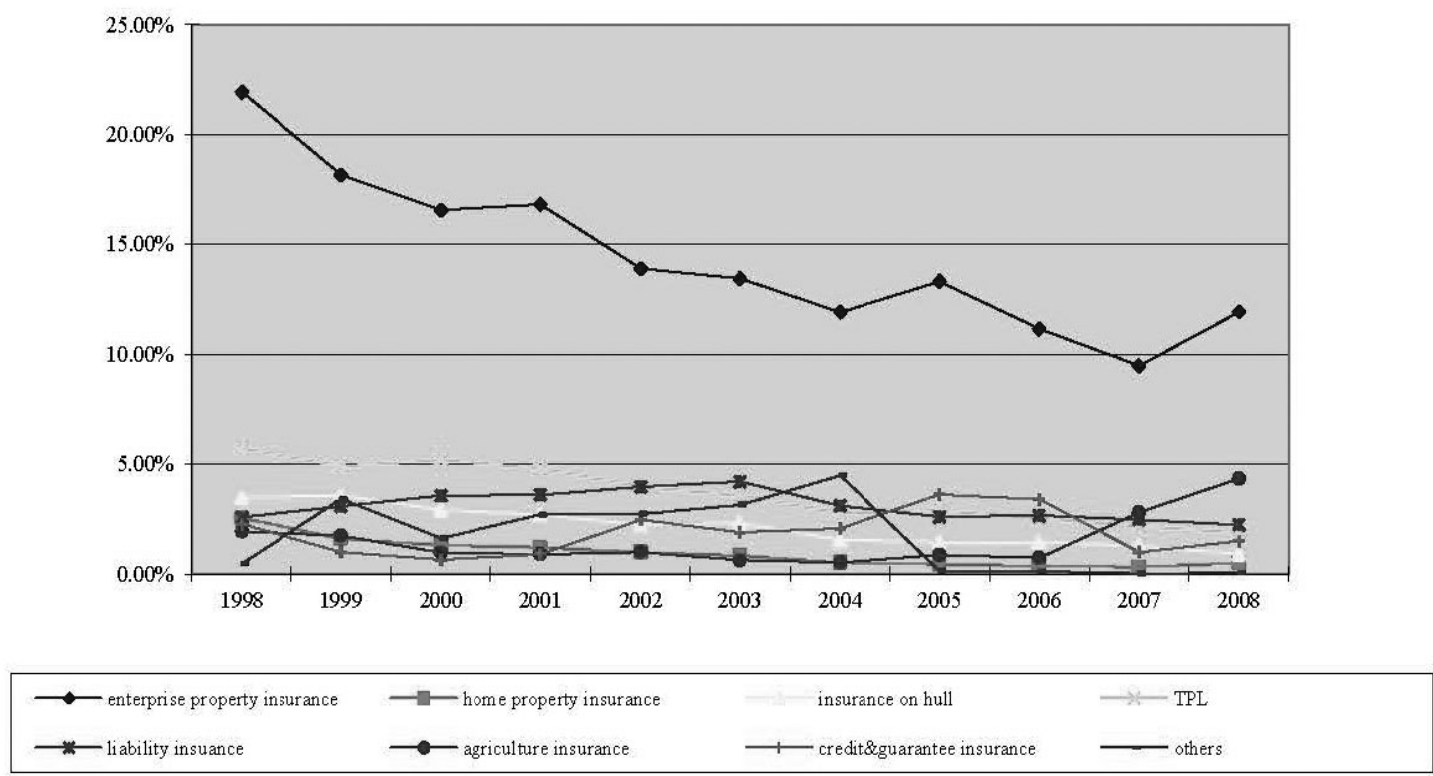

Figure 3. Analysis of compensation of non-auto insurance (1998-2008)

First, the ratio of compensation of enterprise property insurance to the total sum is higher than other non-auto insurance. This type of insurance is traditional, and most of the potential insureds have taken advantage of this 
coverage, resulting in a higher market share. However, the concentration of insurance coverage has created severe competition, leading to higher indemnity claim costs in an aggressive effort to expand this traditional business. From the policyholders' viewpoint, expectations of insurance claims are relatively high, causing the ratio of indemnity claims to premiums written to persist at an unattractive level. Simultaneously, the ratio in corporate property insurance is declining to a more profitable level of underwriting. Reasons given include greater total income of the insureds, and a better handle by insurance companies on the risk exposures being underwritten. As in developed countries, a natural disaster can also cause hardening of the underwriting market, and the Wenchuan earthquake which occurred during this time frame is cited as a catalyst for higher prices and tighter underwriting practices in the commercial market.

Second, compensation of agricultural insurance has fluctuated around 1.03 percent from 1998 to 2006, but appeared to reach a potential inflection point in 2007, and it is at a turning point in 2007, quickly rising to 2.08 percent, again due to governmental policy changes preferential to the agricultural industry. The other lines of insurance are too insignificant at this time to have any meaningful influence on total compensation.

\subsubsection{Research Analysis on Product Homogeneity}

Using an analysis of the coefficient of variation, we investigate the homogeneity of products between different insurance companies, as illustrated in Figure 4 below (Note 11).

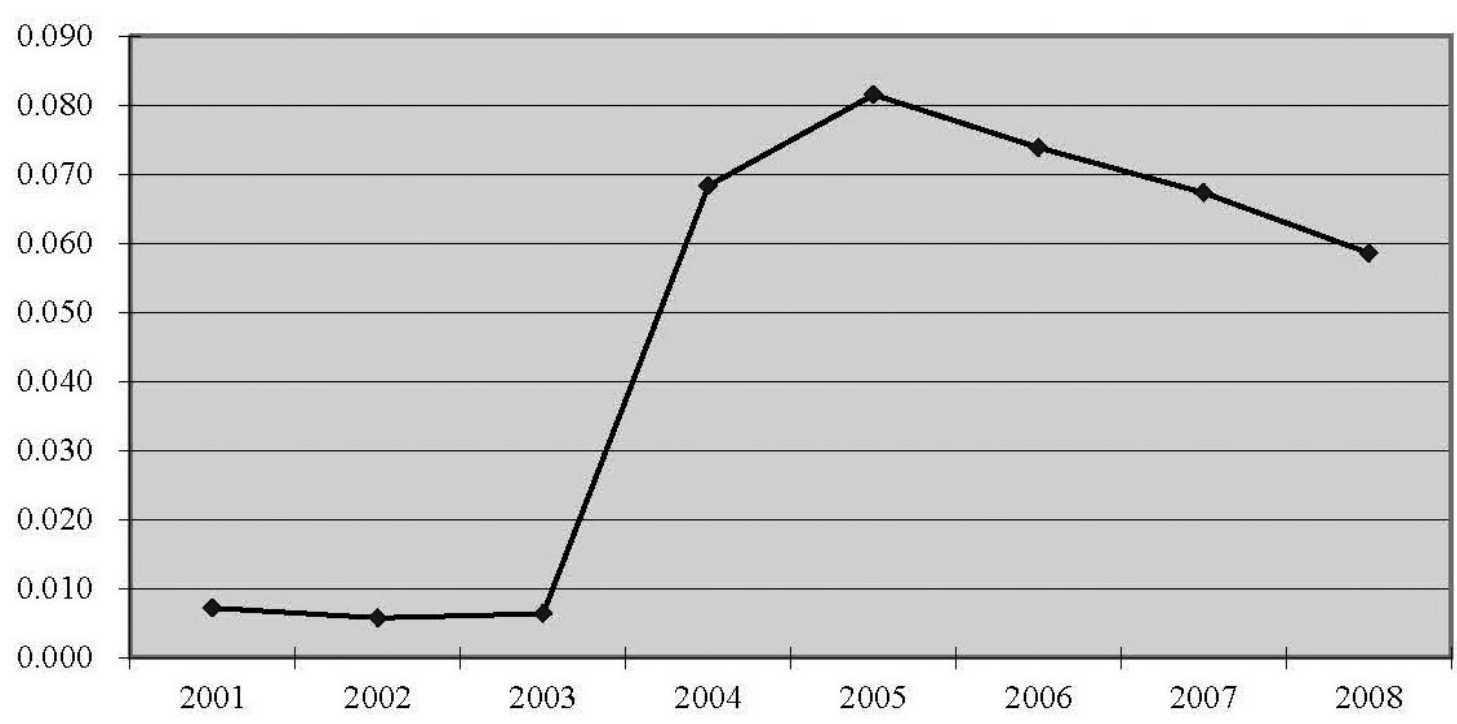

Figure 4. Coefficient of variation in auto insurance (2001-2008)

From Figure 4, we find that the coefficient of variation fluctuated at 0.006 from 2001 to 2003, which suggests that motor vehicle insurance was the main product operated by insurance companies, so the homogeneity of products structure was increasingly severe. The development of the insurance industry in China, coupled with an increase in the number of insurance companies led to a CV in 2004 that suddenly increased to 0.068 , and peaked at 0.081 in 2005. Predictably, the proportion of motor vehicle insurance declined, and the overall product structure was markedly improved. A substantial change in regulatory policy, resulting in Automobile Traffic Accident Third Party Liability Compulsory Insurance, was mandated in 2006. As expected, vehicle insurance sales expanded rapidly. Combined with basically no rights for foreign insurance companies to enter the compulsory insurance market, we find that the CV began to decline and the homogenization of the insurance products structure increased in severity once again.

\section{Optimized Measurements for China's Property Insurance Industry}

In this section we make general suggestions for improved measures to effectively document the structural and operational improvements in the Chinese property insurance industry. Recommended responses to measurement results are also included in this section.

"I often say that when you can measure what you are speaking about, and express it in numbers, you know something about it; 
but when you cannot express it in numbers, your knowledge is of a meager and unsatisfactory kind; it may be the beginning of knowledge, but you have scarcely, in your thoughts, advanced to the stage of science, whatever the matter may be."

-- William Thomson, Scottish physicist

\subsection{Differentiation Strategy}

According to the definition of Industrial Organization Theory, differentiation strategy in property and casualty insurance means the service provided by insurance companies can create special preferences by the insured, and the insured can distinguish it from similar services in other companies. Successful implementation of such a strategy can put a company in a favorable position with respect to market competition. Increased product differentiation should greatly expand consumer options and enhance consumers' welfare.

Currently, China's property insurance market can best be characterized as immature. Any existing business differentiation is a type of administrative monopoly, which is due to the continued transition from a planned economy to market economy. Business differentiation is still at a relatively low level, which is a result of the strong influence of business networking. There is little obvious incentive for insurance companies to become effectively competitive entities in the short term, and competition remains at a comparatively low level. Our suggested themes for moving China's property insurance industry forward are "Optimize the product structure" and "Build the company's core competitiveness."

\section{- $\quad$ Optimize the Product Structure}

(1) Automobile Insurance-Professional Management

Unconstrained expansion of the auto insurance business will lead to increased risk of insolvency, so the implementation of professional management is necessary. We suggest a more in-depth analysis of basic issues in auto insurance; the use of ratemaking to eliminate products with few losses; strengthening financial supervision and regulation on insurance to protect against additional risks with serious losses; and expand on the cost-effective additional insurance popularization, such as risk of breakage. Second, detailed management must be incorporated into vehicle models. Insurance companies should make full use of business systems on vehicles, analyze various car models accurately and track loss ratios and other credible data in various models. Utilization of these steps can result in an underwriting policy of differentiation that can be implemented smoothly. Third, differentiation management should include vehicle use. Companies should consciously reduce the proportion of trading vehicles and expand the coverage of company and high-end private cars.

\section{(2) Non-Automobile Insurance-Key Management}

We recommend that companies develop the home property insurance and enterprise property insurance lines. With the continued development of China's economy, enterprise value continues to rise and household wealth has also increased dramatically, so the demand for insurance products by both enterprises and individuals is urgent. As an example, consider homeowners insurance. Currently, China has more than 300 million households and many families have been accumulating property. According to surveys, even in cosmopolitan Shanghai and other big cities, the rate of family property insurance is estimated at about seven percent. If the rate of insurance coverage is a modest 30 percent (the average coverage rate in developed countries is 80 percent), that would result in 90 million potential customers in the home property insurance market. In view of this situation and market characteristics, property insurance companies should seize the opportunity to increase the development of the personal lines insurance market.

Companies should also make a continual effort to improve agricultural insurance to keep up with the modernization of the agriculture industry in China. There is no doubt that the implementation of subsidies of agricultural insurance by government has benefited agricultural insurance. Property insurers offering this product should seize the opportunities, by developing and improving the agricultural insurance and reinsurance systems. Coordinating with the government to establish financial subsidies or diversification to enable reasonable coverage of catastrophic losses caused by natural disasters is also recommended.

(3) New Types of Insurance-Innovation Management

Rates and price competition should be changed into product competition and new types of innovative products should be developed. An increase in market research and development will likely be a necessary and fruitful capital investment. As with more mature insurance markets in developed countries, a continual move toward a "paperless" system through the extensive use of technological advances will also reap efficiency dividends in the long run. An upgrade of the business structure under the close cooperation with financial and insurance institutions and scientific research is also highly encouraged. Products should be protected through the use of 
patents, and submit new products should be submitted for placement in the category of Intellectual Property Rights.

\section{- Construction of the Company's Core Competitiveness}

The primary source of core competitiveness is the building of core expertise (Note 12), for its survival as essentially a specialized monopoly in a niche market is especially important for small and medium sized insurance companies. As long as the target market is clear, differentiating property and casualty insurance businesses of small and medium insurance companies would be entirely possible and should increase market share, reduce the concentration of the largest insurance carriers, and even change the corporate insurance industry's market structure.

\section{(1) Differentiation Focus Strategy}

This competitive strategy requires all levels of business organizations to properly segment their most profitable markets, select the right target market, and invest resources in this area. In addition, they should actively cultivate the core technical capabilities, increase strategic decision-making capacity and product development capabilities and ultimately achieve economies of scale.

\section{(2) Customer Strategy}

Different demands of disparate customers for the insurance company's product differentiation may provide a realistic opportunity. In the current environment of fierce market competition, small insurance companies need to improve risk pricing technology to enhance security capabilities, consider the basic requirements for risk diversification, enhance consumer satisfaction and risk preference analysis, and increase the anti-disaster loss mitigation. These goals are all possible in the current homogeneous insurance market. With clear target market segmentation, the uniqueness of the company can be matched with said markets, which will achieve difference in the design of insurance products.

\section{(3) Technology Innovation Strategy}

A necessity for market leading positions in today's world is an accumulation of experience, state-of-the-art technology, and a continuous improvement in the areas of technology, actuarial, underwriting, and risk management techniques. This will mitigate the risk of having the insurance business imitated by creating a moat around pioneering insurance product offerings.

\subsection{Regional Coordination Development}

The insurance companies should adjust product development and marketing strategy by making it responsive to diverse regional characteristics, promoting regional coordination and forming a pattern of succession and cooperation among the central, eastern and western areas of China.

\section{- The Leading Role of China's Eastern Region}

As the most advanced area for the insurance industry in China, the eastern region is rich in insurable resources, which has lead to an increased need for the pooling mechanism provided by insurance market stakeholders. In order to address international market competition, the domestic insurance industry in China must develop new products; open up new areas of business; and update product construction by increasing the content of business techniques. From the above analysis, we predict that cargo insurance and property insurance will have greater business potential in the eastern region. The eastern region is poised to make full use of its economic advantage, technology, talent, and resources to develop advantageous products, update product construction, and enhance capability for sustainable development. Moreover, the eastern region should take the lead for developing insurance lines that have a low coverage ratio, such as credit \& guarantee insurance and liability insurance.

\section{- Promoting Business in the Central and Western Regions}

With a long history heavily influenced by a mixture of economic, societal, geographical, cultural, customs and religious beliefs, the insurance market in the central and western regions is admittedly not mature by acceptable measures. The key to accelerating insurance in these regions depends on education about the risk transfer role of insurance in society. Developing products to match these potential insurance consumers is challenging yet also necessary. Broadening of the channels of insurance and investing in the human resources talent to carry out these objectives will also advance the penetration of the insurance industry into these regions. The gradual improvement of western Chinese infrastructural facilities, will require engineering and special insurance protection for roads, railways, airports, telecommunications and water conservancy. 


\section{Conclusion}

In this study we have performed a comprehensive analysis of the Chinese property insurance business structure as it currently stands. Our first observation is that while the market concentration of Chinese property insurance is high, efficient economies of scale have yet to be achieved. Stated another way, a higher market share is not accompanied by a higher return on assets.

Secondly, some features still prevalent in the Chinese insurance industry are obsolete on a global basis and up to now the determination of the optimal product mix and structure has been a somewhat intuitive undertaking. Since the insurance business is relatively concentrated, high dependence on a single line of insurance has served to curtail overall development of the industry. For too many companies, the performance of the motor vehicle insurance line determines the success or failure of the entire insurer.

Thirdly, the influence of governmental policy in China is significant and warrants greater consideration from the insurance industry. Two obvious examples are the implementation of Automobile Traffic Accident Third Party Liability Compulsory Insurance and policy-oriented Agricultural Insurance. These regulations, either directly or indirectly, influence product structure.

Future suggested studies include deeper research into the impact of macro-controls, and methodologies that may be employed to enhance property insurers' profitability and optimize their operational efficiency. This stream of research could also be expanded to compare the impact of equity fund investments, corporate debt investments, underwriting and claims management, etc. on the profitability of China's property casualty insurance industry.

\section{Acknowledgements}

The authors would like to thank the journal's reviewers and attendees of the Asia-Pacific Risk and Insurance Association for their helpful comments on earlier drafts of this paper. A special thank-you is extended to Doris Rios of New Mexico State University for her formatting expertise.

\section{References}

Bain, J. S. (1968). Industrial Organization: A Treatise (2nd ed.). Hoboken, NJ: John Wiley.

Yearbook of China's Insurance. (2009). Editorial Office of Yearbook of China's Insurance.

Cummins, J. D. (1988). Risk-based premiums for insurance guaranty funds. Journal of Finance, 43, 823-839. http://dx.doi.org/10.2307/2328138

Cummins, J. D. (1993). Measuring Cost Efficiency in Property Liability Insurance Market. Journal of Banking and Finance, 17, 463-482. http://dx.doi.org/10.1016/0378-4266(93)90046-G

Cummins, J. D., \& Dionne, G. (2008). Dynamics of Insurance Markets: Structure, Conduct, and Performance in the 21st Century. Journal of Banking \& Finance, 32(1), 1-3. http://dx.doi.org/10.1016/j.jbankfin.2007.09.001

Cummins, J. D., \& Weiss, M. A. (2000). Analyzing firm performance in the insurance industry using frontier efficiency and productivity methods. Handbook of Insurance (pp. 767-829). Springer Netherlands. http://dx.doi.org/10.1007/978-94-010-0642-2_24

Dionne, G., \& Harrington, S. E. (1992). An Introduction to Insurance Economics. In Dionne, G., \& Harrington (Eds.), Foundation of Insurance Economics (pp. 1-48). Boston, MA: Kluwer Academic Publishers.

Hao, Y. (2002). Insurance. Beijing: Tsinghua University Press.

Huang, D., \& Query, J. T. (2007). Designing a New Automobile Insurance Pricing System in China: Actuarial and Social Considerations. CAS Forum, Winter Forum.

Jiang, S. Z., \& Yi-qiao, S. (2000). The economic analysis of China's Insurance Industry. Insurance Studies, 3, 20-22.

Lei, T. (2006). Rational view of the structural adjustment. China Insurance, 5, 45-47.

Lu, L. (2002). Product Innovation. China Insurance, 6.

Scherer, F. M. (1970). Industrial Market Structure and Economic Performance. Chicago: Rand McNally.

Sun, Q., \& Li-Ming, S. (2002). A Review of Insurance Economics Study. Economic Research, 5, 48-57.

Swiss Re Investor Inc. (2000). Asset-Liability Management for Insurers. Sigma, 6, 1-36.

Wang, X. (2009). Analysis of the Property and Casualty Market in China. Insurance Studies, 1, 25-40. 
Wei, H. L., \& Qian, W. X. (2001). WTO rules for the insurance industry and international practice. Beijing: China Integrity Press.

Williams, C. A., Young, P. C., \& Smith, M. L. (1998). Risk Management and Insurance. Boston, MA: McGraw-Hill.

Witt, R. C., \& McCabe, G. M. (1976). A simulation analysis of capital structure in a property insurance firm. Journal of Risk and Insurance, 43, 721-726. http://dx.doi.org/10.2307/252036

Zhou, Y. (2007). China's Insurance Market Structure, Conduct and Performance. Beijing: Economic Science Press.

\section{Notes}

Note 1. PICC is short for Property and Casualty Company Limited

Note 2. PING AN is short for Ping An Property \& Casualty Insurance Company of China, Ltd.

Note 3. CPPI is short for China Pacific Property Insurance Co., Ltd.

Note 4. CIC is short for China United Property Insurance Company

Note 5. TIAN AN is short for TIAN AN Insurance Company

Note 6. CCP is short for China Continent Property \& Casualty Insurance Company Ltd.

Note 7. http://stats.oecd.org/glossary

Note 8 . The difference between Structure I and II is the number of the entities in one industry. In Structure I, there are only about 20-40 entities, for example the motor line. In Structure II, more entities will be included, about 40-200, such as the tire industry as an example. For more details on this theory, see Bain, J. (1956), Barriers to New Competition. Cambridge, Mass: Harvard University Press.

Note 9. Using the "China Insurance Statistical Yearbook"(1999-2009), we are able to calculate premium income, claims expenditure and some ratios for major types of insurance (1998-2008).

Note 10. Data show that, premiums of liability insurance and credit insurance in the market economy countries (e.g., Western Europe, North America, Japan, etc.) account for $35-50 \%$ of property and casualty insurance.

Note 11. In probability theory and statistics, the coefficient of variation $(\mathrm{CV})$ is a normalized measure of dispersion of a probability distribution. It is defined as the ratio of the standard deviation to the mean: $\mathrm{CV}=\sigma$ / $\mu$. Restricted by the Chinese law, foreign-fund insurance companies cannot sell compulsory insurance. Therefore, we only use the data of Chinese property insurance companies (2002-2008).

Note 12. A Company's core competitiveness is the most fundamental one with regard to long-term stability of competitive advantage and sustainable excess profits.

\section{Copyrights}

Copyright for this article is retained by the author(s), with first publication rights granted to the journal.

This is an open-access article distributed under the terms and conditions of the Creative Commons Attribution license (http://creativecommons.org/licenses/by/3.0/). 